\title{
Gamified Kit That Will Raise Children's Environmental Awareness And Reduce Visual Pollution in Urban Landscapes
}

\author{
Pelin Asur \\ Department of Planning, Design, Architectural Technology, \\ Faculty of Architecture Sapienza Universita Di Roma, Italy \\ E-mail: hello@pelinasur.com \\ Feran Asur \\ Department of Landscape Architecture, Faculty of Architecture-Design, \\ Yuzuncu Yil University, Zeve Campus, 65090 Tusba/Van, Turkey \\ E-mail: feranekasur@gmail.com
}

\begin{abstract}
In today's world, more than half of the population lives in cities, and the amount of solid waste increases in parallel with the worldwide population increase. Cities face the problem of waste and recycling, which affects their image and causes visual pollution for the landscape, and efforts are being made to solve this problem. Conscious societies go from large scale to small scale solutions, from trash exchanges from other countries to modifying trash cans in the city. In order to maintain awareness, as well as adults, the education of environmental awareness of today's children who are adults of the future should be given great importance.

In the study; BeTo kit was designed as a product concept based on sustainable awareness philosophy in order to provide solutions to these problems and to reduce visual pollution. This kit, which will be distributed to elementary classes, is a fun way to teach elementary school students how to sort and recycle garbage with gamification technique in collaboration with Retake Rome. Retake Rome is a movement of citizens, non-profit and non-party, engaged in the fight against degradation, in the enhancement of public assets and in the diffusion of civic sense in the territory. In the operation of the system, BeTo kit will be distributed to schools and waste will be separated and collected. The kit is designed to improve the sustainability of the livable environment and the visuality of the landscape. The kit designed for this application will contribute to product designers, environmental engineers, landscape architects, ecologists, primary school educators and other related disciplines in the studies to be conducted on the basis of improving the sustainability of the habitable environment and the visuality of the landscape in urban areas. In addition, it is thought that the proposed application will serve as a basis for municipalities and other city stakeholders for physical, social, and ecological studies in urban areas in the future.
\end{abstract}

Key words: Sustainable environment, visual landscape, urban area, education, iot.

DOI: $10.7176 / \mathrm{JSTR} / 6-02-03$

\section{Introduction}

Urban landscapes are shaped by natural and social processes that occur in the urban fabric (Matusoka and Kaplan 2008). In the globalized, world this is the case in most developing countries, where rapid economic growth and industrialization have transformed the landscape of significant impacts. The greatest impact of urbanization is the increase in the amount of waste produced (Read, 1999; Öztürk, 2010; Y1lmaz and Bozkurt, 2010; Gündüzalp and Güven, 2016; Amritha and Kumar, 2019). Disposal of waste is one of the most important impacts of urbanization and has adversely affected the urban landscape quality of cities, especially in developing countries. One of the first studies on visual perception of cities in Europe was made by Cullen (1961). Anthropogenic studies on landscape quality and the basis of landscape perception were made by Taylor et al. (1987), Zube (1987) and Smardon et al. (1986).

The concept of visual landscape quality in urban areas has a significant impact on urban image (Turgut, et al., 2012). The negative visual impact, called image pollution or visual pollution, can generally be 
expressed as all the disturbing images within the natural and cultural environment. In the present century, awareness of the problems caused by visual pollution arising from environmental pollution has been realized and various studies have been initiated to prevent it.

The physical environment is a dynamic phenomenon that includes natural, cultural, historical, social and artificial elements, including human beings, and these phenomena undergo a continuous and variable interaction with each other. Urban environments consist of positive and negative elements, including structures and the outdoor spaces they describe. Lines that make up the surfaces of positive and negative elements in urban environments, material, color, texture characteristics of the surfaces, facade proportions of buildings, quality of openings and facade decorations are also important factors in determining the quality of urban environment. When all these values come together, city macroform and city skyline are formed for the whole of the city, and when examined in detail, micro-scale urban aesthetics and the concept of environment with beautiful / attractive appear (Erdoğan, 2006).

Although a wide variety of solutions to environmental problems are proposed, it is most noteworthy that the problems are prevented before they emerge at the source. According to Şimşekli (2004), it is accepted by many circles that education is the most important factor for this. For this reason, many organizations such as UNESCO, UNEP, Ministries of Environment, Universities, Municipalities and Some NGOs are carrying out studies based on environmental education. Environmental education is defined in various ways: Erten (2004) defines environmental education as the development of attitudes, value judgments, knowledge and skills for environmental protection and demonstration of environmentally friendly behaviors. Akçay (2006) states that environmental education; individuals' biological, social and physical environment related values, attitudes, concepts are summarized as. Ozaner (2004) describes environmental education as teaching the language of nature. Creating environmental awareness among children is an important step towards sustainable development and taking necessary protections for a more livable world (Akbayrak, \& Turaşli, 2017).

The basis of environmental education is to protect nature and natural resources. The main objective of environmental education is to gain positive and permanent behavioral changes and to ensure the active participation of individuals in the solution of problems. Children's environmental education can be systematically and regularly developed in pre-school and primary education. According to the studies, if environmental education is given in a visual, auditory and practical way at early ages, it is seen that it increases environmental knowledge and sensitivity among students (Şimşekli, 2004).

Within the scope of environmental education, children play games that make nature-loving and experience life in nature. Through these games and experiences, children acquire positive emotions and learn to be environmentally friendly. With this reflection, urban areas have better quality spaces in terms of visual landscaping, free from image pollution caused by solid wastes.

From this point of view, the system established in this study aimed to strengthen the bonds of elementary school students with nature, to inform them about the recycling of materials, to realize the power of the community and to contribute to the development of environmental awareness and to create better quality spaces visually.

In many parts of today's world, various studies are carried out effectively in order to minimize the negative effects of the environment. Retake Roma, a voluntary establishment in Rome, was established to raise environmental awareness. The story of Retake Roma began whith an American woman resident in Rome rebelled against graffiti on the building of her house. Retake Roma, which grows rapidly with the participation of the local people, has various activities. Some of them are culture tours, gathering with the residents and the nearest park, cleaning the environment, painting and retake school activities. In order to raise awareness of children and to improve environmental awareness in the Retake School event, volunteers attend classes in schools and explains why we should not pollute the environment and how important and valuable a clean environment is. In addition to this, this idea is reinforced with various games.

A project was developed to support the social development of children and to overcome the importance of environmental awareness and collective action. The product was designed and modeled to explain to children how to dispose of the materials, how much they protect the world in this case, and how big the impact is when they are made collectively. The aim of this project, which was carried out in cooperation with Retake Roma in an individual way, is to strengthen children's ties with nature, which is the basis of the landscape, to contribute to the education of the environment, to raise awareness and to help build a clean future and to support their social development. 


\section{Materials and Methods}

The study was conducted in Rome. On-site observations, investigations and oral interviews were conducted with urban residents on environmental pollution. The literature was used as an auxiliary material in the study. In the research, shadowing and netnography techniques were used. During the project participation was provided for approximately two months in Retake Roma activities. These activities include three types of activities: retake culture, retake classic and retake school. In the Retake classic event, together with the volunteers living in the same neighborhood, waste collection and graffiti cleaning activities were carried out at the park or metro stations designated by the volunteers. Retake culture tour was done by cleaning the environment while visiting historical sites. Which attracted the attention of many people and increased awareness. Although these two activities were for adults, it was noteworthy that young children were also involved and that they were entertained. It was noticed that the participation of children in the activity was due to their families and teachers. The Retake School event consisted of speeches addressed directly to primary and secondary school students. In the study played with elementary school students' who collects the fastest? and the related notes were prepared.

\section{Findings}

In the conversations with children before and after the event It was revealed that the activities had great effects. It was stated that the effects of the activities on the children were undeniable in the interviews conducted with the parents as well as the Retake Roman volunteers. Following the results of shadowing, netnography and oral interviews, the system and the product developed by the design thinking method were used to help the primary school students to strengthen their ties with nature, to inform them about the recycling of materials, to realize the strength of the community and to improve environmental awareness.

The name of the product that was designed and developed is BeTo '. In simple terms, BeTo is a product that tells children that materials must be separated and disposed of and how big the effect is if they are made in mass. His motivation is to tell us how much we protect the world.

BeTo is a smart product that can count the collected waste, see active users that protect the environment and demonstrate the increased number of users. BeTo is distributed to students in a kit that includes gloves, recycled bags and a user manual.

According to the system (Figure 1.), the teacher, who is responsible for primary school students, arranges the program to do class activities without interrupting the curriculum. Primary school students are taken to the neighborhood walk by their teachers. The purpose of the walk is to collect the wastes in the environment by classifying them in order to create awareness among students.

In the gamified system, students fix the bag in which they will collect the waste to the designed BeTo. When the fixing is finished the user begins to actively appear in the application that BeTo is connected to. BeTo, which has a gps receiver and counter sensor, counts waste collected according to types (glass, cardboard, plastic, etc.) and the mobile application tool allows us to see where and how much we protect the world. The mobile application, which actively shows the people who protect the world, is a source of motivation for other users. In addition to these, each BeTo that is activated has the feature of emitting light in a certain scale. The light intensity of BeTo, which aims to influence the social awareness and motivation, increases in direct proportion with the number of active users at the same time. 

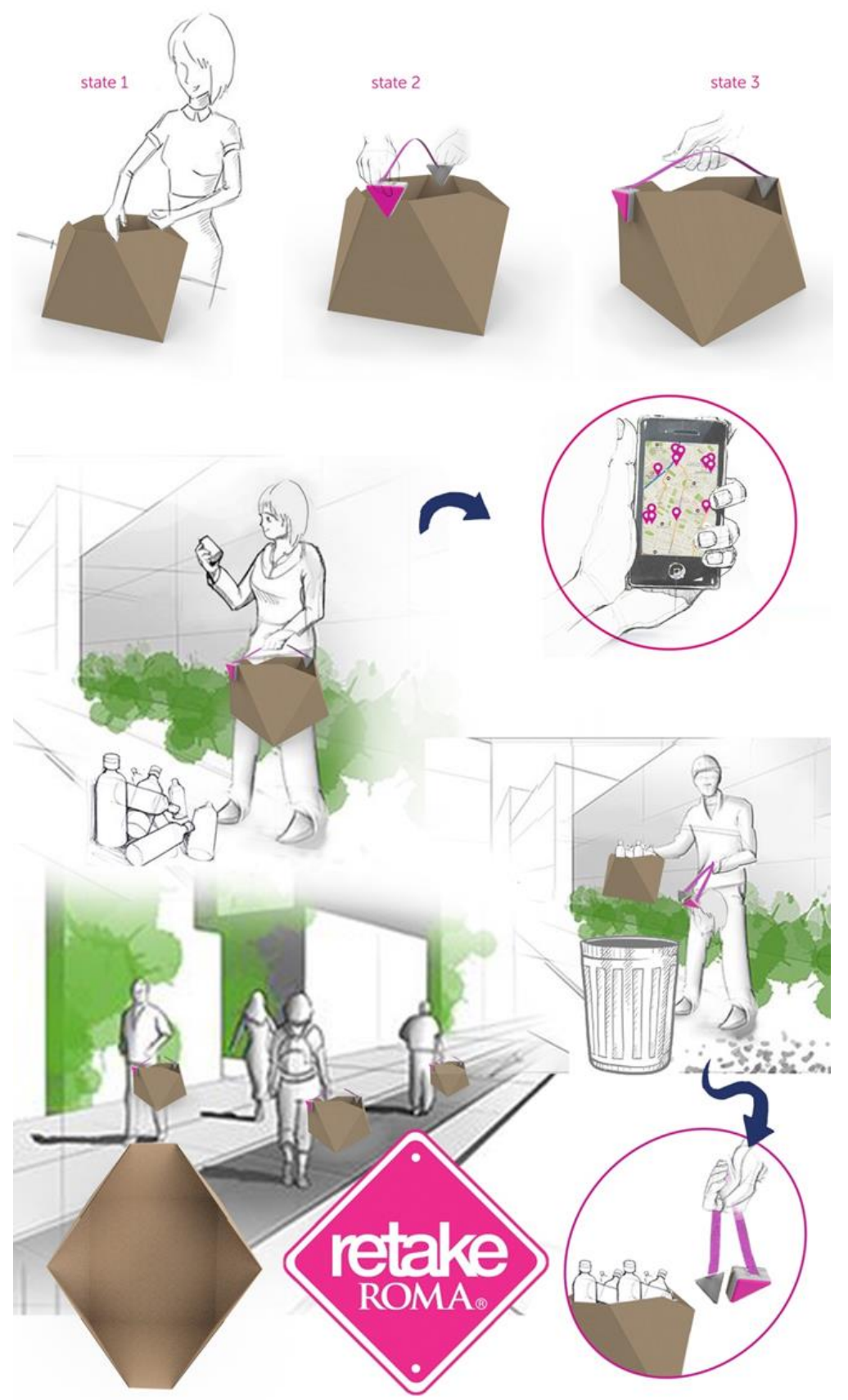

Figure 1. Gamified System

While designing the BeTo form, it was inspired by the recycling symbol and the Retake Roma logo (Figure 2.). BeTo basically has 3 main goals. In order to fulfill these three main targets, GPS, light sensor and counter sensor were used (Figure 3.). GPS determines the location of active environmentalists. In order to increase motivation, it shows the location to other volunteers who are registered to the system and want to contribute, and invites them to the environmentalism. The intensity of the light sensor increases as environmentalists become active, and besides creating awareness visually, it expresses the feeling that we are better together. The counter sensor reports every waste collected from the environment to the system and shows how much the world (by whom or which school) has been saved. Thus, the rate of motivation and sensitivity in people attending the event also improves significantly. After the event, the bags are discarded and the BeTos remain in the student for use at the next event. Thanks to being washable material, there is no problem with hygienic pain. 


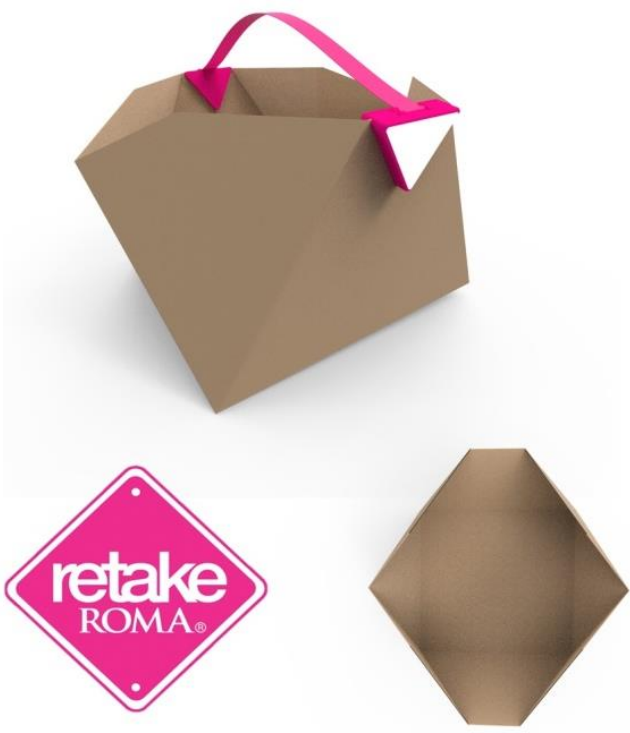

Figure 2. BeTo Shape

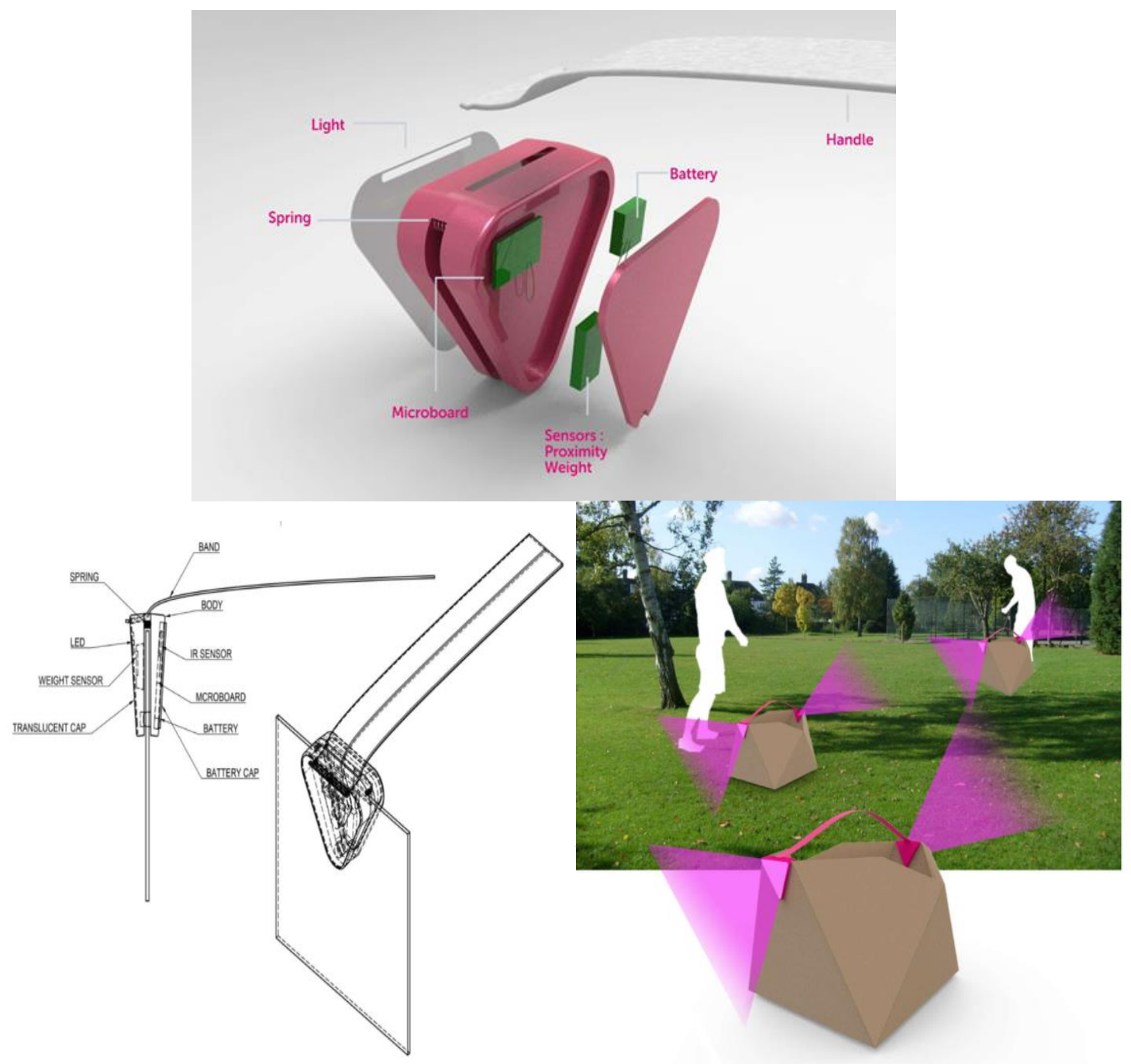

Figure 3. BeTo Sensors 


\section{Results}

With the impact of industrialization and urbanization in the globalizing world, resources are used unconsciously and wastes are generated as a result of this consumption. The problem of waste increasingly encountered; it affects society, family and the individual.

In the study; BeTo kit was designed as a product concept based on a sustainable awareness philosophy in the context of providing solutions to these problems and enabling the reduction of visual pollution. The aim of this product, which was designed with the motto 'We are better together, we are stronger', to attract the attention of the local people beside students and families.

This system can be turned into the most environmentally friendly school race among schools. The motivation to be environmentalists increases the number of activities and thus awareness. This service design will contribute to product designers, environmental engineers, landscape architects, ecologists, primary school educators and other related vocational disciplines in the works to be carried out in urban areas on the basis of sustainability of the livable environment and improving the visibility of the landscape. As the applicability of this designed product is easy and interesting, it is suggested that it will be efficient especially in big cities and it is recommended to be used. It is thought that this application, which is designed because the concept of visual landscape quality has an important effect on the city image, will form a basis for the municipalities and other city stakeholders in the future physical, social and ecological studies.

\section{References}

Akbayrak, N., \& Turaşl1, N. K. (2017), Oyun temelli çevre etkinliklerinin okul öncesi çocukların çevresel farkındalıklarına etkisinin incelenmesi. Erken Çocukluk Çalışmaları Dergisi, 1(2), 239258.

Akçay, İ. (2006), "Farklı Ülkelerde Okul Öncesi Öğrencilerine Yönelik Çevre Eğitimi”. (Yayınlanmamış yüksek lisans tezi). Uludağ Üniversitesi, Sosyal Bilimler Enstitüsü, Bursa.

Amritha, PK, ve Kumar, P.A. (2019), Kentsel alanlarda sürdürülebilir bir organik atık yönetimi seçeneği olarak verimli manzaralar. Çevre, Kalkınma ve Sürdürülebilirlik , 21 (2), 709-726.

Cullen, G. (1961), The concise townscape. Kidlington, GB: Elsevier Ltd.

Erdoğan, E. (2006), Çevre ve kent estetiği. Bartın Orman Fakültesi Dergisi, 8(9), 68-77.

Erten, S. (2004). Çevre eğitimi ve çevre bilinci nedir, çevre eğitimi nasıl olmalıdır. Çevre ve İnsan Dergisi, 65(66), 1-13.

Gündüzalp, A. A., \& Güven, S. (2016), Atık, çeşitleri, atık yönetimi, geri dönüşüm ve tüketici: Çankaya belediyesi ve semt tüketicileri örneği. Hacettepe Üniversitesi Sosyolojik Araştırmalar EDergisi, ISSN, 1304-2823.

Matusoka, R. H., \& Kaplan, R. (2008), People needs in the urban landscape: Analysis of landscape and urban planning contributions. Landscape and Urban Planning, 84, 7-19.

Ozaner, F. S. (2004),. “Türkiye'de okul dışı çevre eğitimi ne durumda ve neler yapılmalı?” V.Ulusal Ekoloji ve Çevre Kongresi, 5-8 Ekim 2004, Taksim International Abant Palace, Abant İzzet Baysal Üniversitesi \& Biyologlar Derneği, Abant-Bolu. Bildiri Kitabı (Doğa ve Çevre), (ss.6798), Biyologlar Derneği, İzmir.

Öztürk, İ. (2010), Katı Atık Yönetim ve AB Uygulamaları. İSTAÇ A.Ş. Teknik Kitaplar Serisi 2, İstanbul.

Read, A. D. (1999), A Weekly Doorstep Recycling Collection, I had no Idea We Could Overcoming the Local Barriers to Participation. Resources, Conservation and Recycling, 26, 217 -249.

Smardon, R.C., Palmer, J.E., and Felleman, J.P., 1986. Foundations for visual project analysis. New York: John Wiley and Sons. 
Şimşekli, Y. (2004), Sensitivity of Elemantary Schools to the Environmental Education Activities For Increasing Environmental Knowledge. Uludağ Üniversitesi Eğitim Fakültesi Dergisi, 17(1), 83 92. http://kutuphane.uludag.edu.tr/Univder/uufader.htm.

Taylor, J.G., Zube, E.H., and Sell, J.L. (1987), Landscape assessment and perception research methods. In: R.B. Bechtel, R.W. Marans, and W. Michelson, eds. Methods in environmental and behavioral research. New York: Van Nostrand Reinhold Company, 361-393.

Turgut, H., Atabeyoğlu, Ö., Yılmaz, H., \& Irmak, M. A. (2012), Evaluating different planting design compositions for visual landscape quality in street planting.

Yılmaz, A. and Bozkurt, Y. (2010), Türkiye'de Kentsel Katı Atık Yönetimi Uygulamaları ve Kütahya Katı Atık Birliği (KÜKAB) Örneği. Süleyman Demirel Üniversitesi İktisadi ve İdari Bilimler Fakültesi Dergisi, 15(1).

Zube, E.H. (1987), Perceived land use patterns and landscape values. Landscape Ecology, 1 (1), $37-$ 45. doi:10.1007/BF02275264. 